Environment Conservation Journal 16 (SE) 145-149, 2015

ISSN 0972-3099 (Print) 2278-5124 (Online)

Abstracted and Indexed

\title{
Form and Meaning of Rostam and Esfandiyār Battle in a Coffee House Painting by Mohammad Modabber
}

\section{Leila Taghavi}

Received:30.07.2015

Revised:25.08.2015

Accepted:30.09.2015

\begin{abstract}
Coffee house painting was a new phenomenon in the history of Persian painting, which, along with the preservation of all rational religious and traditional art values, was born to the need of the people and to respect people's beliefs. Shahnameh stories were a proper field for creation of epic images of chivalric men who always stood up heroically to the honor and dignity of their mother land at any time, like RostamDastan.In this regard, a coffee house painting of "The battle of Rostam and Esfandiyār" by Mohammad Modabber from Shahnameh epic text is examined to understand the meaning of the image by analyzing its lines and patterns. Opening this path and through the way passed to understand the meaning, recognizing the special contracts used by Mohammad Modabber in the coffee house painting of "The battle of Rostam and Esfandiyār" and its various implications sound highly necessary.
\end{abstract}

Keywords:Form, Meaning, Coffee House Painting, The Battle of Rostam and Esfandiyār, Muhammad Modabber.

\section{Introduction}

The origins of coffee house painting should be sought in the rituals of Mourning for Siavash and Iraj Enmity that are from pre Islam era and were held every year in a certain time. After Islam these rituals transformed to Ta'zieh of Imam Hussein (AS) and his companions with a religious form and meaning to establish Shiism.But the development of modern Iranian painting apart from mysticism, art, illuminated manuscripts, and besides charm and miracle of bold and beautiful tiling patterns, and other expressions of indigenous art, form when they blend with national and local legends. There is no doubt that in this great blending, the wisely thoughts of the great Ferdowsi play a fundamental and effective role. Talented artists, with the help of Shahnameh stories and by illustrating them, have tried to do their share and contributed to maintaining the rich heritage of Iranian culture. This is nothing but resistance to relentless political and cultural attacks by foreign nations to the soil of Iran. In this regard, coffee house painting of "Rostam and Esfandiyār Battle" by Mohammad Modabber from epic text ofShahnameh is

Author's Address

plaque 8, alley 744, Ghiam Avenue, first phase, Fasa,Shiraz education and training organization district 3 Fars, Iran

E-mail: 1_taghavi24@yahoo.com examined to reveal its explicit and implicit meanings by analyzing the patterns and designations.

\section{Background}

Saeed Nafisi in the introduction of Masterpieces of the Contemporary Literature in a discussion about literary schools; Farhad Nazerzadeh Kermani in the first volume of the book Symbolism in Dramatic Literature; Mohammad Jafar Yahaghi in Dictionary of Mythology; Hussein Ramzjoo in the ideal and perfect man in epic and mystical literature; and especially Taghi Poornamdaryan with his full and effective discussions in secret and secret stories were more successful than others in explaining the old symbolic and rhetorical literature in Persian literature. There are also some researches and articles on Coffee House Painting. A reflection on all of them leads to the conclusion that each of them had only considered a part of the overall theme which was the incentive for us to study more.

Aesthetic convention of coffee house painting

Contract in literary definition means "a union or an agreement of people to achieve the same thing" (Moein, 1993, pp 26-52). If this definition refers to art and artistic communication, we will be faced with three distinct components. First, art as a matter 
of an agreement and share. Second, the artist as a creator of artistic work that provides a particular form and meaning. Third, the audience that perceives feeling or thought by senses. Without considering the artist's ability, perception and cognition of artistic tools and discovering methods of expression and artistic creation, and the ability and readiness to understand his work as well; art is the complex basis for the collected tools and elements that suffers from some restrains within itself.

The method of coffee house painting is rooted in religious symbols and "primitivism" prevailing in society and public customs (tradition) and includes the following contracts:

- To consider cultural, ethnical, religious originality

- To contemplate people's awareness and consciousness

- To avoid foreign culture

- To avoid individualism and to emphasis teamwork

- Humility and modesty and lack of effort to achieve fame

- To display aesthetic features of the work and to avoid displaying evil

- To use limited oil-based paints with symbolic meaning

- To apply arabesque designs

- To magnify designs and pictures that are the gist of the text

- The harmonization of designs and their meanings, the relevance of topic to content

- To use all aspects of the panel

- Concentration of the combined elements around a central effect

- To avoid empty space, fill the vacant spaces with compact element

- The atomistic view, the material universe is composed of minute particles, which are considered to be relatively connected to expletive particles.

- To add dimension to the picture by applying the combined elements at the top and on the sides.

Finally, artist provides contracts through codes and signs so that addressee perceives and understands these contracts by their common and connected meanings.

\section{Understanding the Image}

Analyzing each image leads to an inevitable question which is the comparison between what is expressed and what does it express, that is the similarity between them. But, do we need to use this comparison in order to identify and examine images? While we are reading each image, we substitute its elements with other concepts. For Jean Paul Simon, there are two types of codes: technical codes and anthropological codes. The former refers to codes that is used in recreating topics and the latter refers to codes that are relevant to culture and knowledge of addresses (Ahmadi, 2003, 126).

According to Zamiran (2005, pp 132-133), the addressee or audience would understand set of codes of the work and his means perceiving thoughtful aspects of image. Moreover, interpreting and communicating with the text requires familiarity with set of codes so that impossible interpretations do not reveal "sign".

Identifying different aspects of each visual expression reveals an important point that is each work is created in a particular historical-social situation, and any point devoted a specific function; however, it may change or eliminate in another situation. Therefore, recognizing symbols and signs should be analyzed based on the time of their creation. Thus, each image would have a message and a word to express that representing the value of each image as new reality not an imitation of reality.

\section{Coffee House Painting of Rostam and} Esfandiyār Battle by Mohammad Modabber

Modabber was orphaned at age seven. In his early ages he played the role of one of Moslem's children in Ta'ziehs held in Dowlat Tekyeh. At the age of ten or twelve he was apprenticed to master Ali Reza Gollar. He met Hussein the son of master Ali Reza at his tile-making workshop. In the workshop, both of them learned secrets of painting and coloring on tiles and vied with each other in the art of painting and designing. Modabber started painting on canvas and curtains in the coffee houses with encouragement and arrangement of Hussein Gollar,his childhood and painting friend. In the 
coffee houses of Sarpol of Darband, Mash Safar coffee houses in Seyed Esmaeil square and Abbas coffee house he painted on curtains and canvas according to the coffeehouse keepers orders and made a living. Master Mohammad Modabber was the second founder of the coffee house school of painting. He had a strong and glorious painting method in illustration of events of Karbala and religious epics on curtains and canvas. When Master Mohammad Modabber reached the summit of fantasy painting art, he moved slightly away from common tradition in the art of coffee house painting of which he was one of the founders, and by innovation in any traditional art, he started to paint landscapes. This master of coffee house painting school and heartbroken painter of Ashura, died in his stall at a cold and snowy night in winter of 1346, a year after the death of his old friend, Hossein Gollar. The stall, according to the Shahnameh reader Mr. Seyed Davood Jafarpoor, was a small workshop of Haj Ali Agha, known as Haj Ali Siah (black). It was a workshop of building painting on the old Shapoor Street, in front of the Razi hospital. Haj Ali Agha and a few others took the frail body of this artist to Mesgar Abbad and buried him there.

- Elements of nature such as mountains, rocks and desert which are the apparent signs of fixed and moving nature have framed the battle of these two heroes in their heart.

- The main characters of Rostam and Esfandiyār are placed in the center of the painting.

- The specific point of these characters is that Rostam is placed on the left due to the importance of his character and Esfandiyār is placed on the right.

- Rostam have drawn the bowstring and pointed the arrow towards Esfandiyār's eyes.

- Rostam is larger and placed more in front or in the initial plan because of the importance of his character.

- Both characters are wearing war clothes, hoods and feathers and have a great horse, all of which reflect their particular and high position.
- In contrast to the stillness and silence of the landscape, main personages of the painting are in mobility and movement. This is welldrawn by the artist in the dynamic state of characters and their horses.

- Colors are vivid, lively and sometimes come close to reality which was due to the closeness of Modabber to reality and nature.

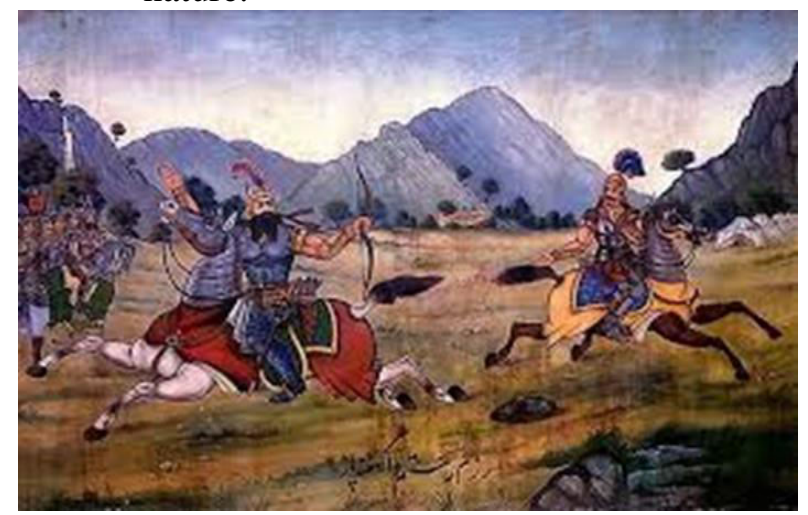

Picture 1. Battle of Rostam and Esfandiyār (Source: Modabber, Sa'd Abad Cultural Complex) The story of Rostam and Esfandiyār Battle Goshtasb and Zarir; sons of Lohrasb. Goshtasb was handsome and a hero. So that after Rostam there were no one as good as him. Two Kaykavousi princes were with Lohrasb and had drawn the king's attention to themselves. Goshtasb envied them and wanted the monarchy under the reign of his father. As Lohrasb refused his request he became resentful and went out of Iran, and finally got to Rome (Greece), and after many master stroke and suffering, Katayoon the daughter of Kaiser was intrigued by Goshtasb and married him.

King of Rome, prompted Goshtasb to move the army to attack Iran. By Lohrasb's command, Zarir went to fight back the Romans and recognized Goshtasb from some signs and returned him to Iran. Lohrasb gave the kingdom to him and went to worship God.

After withdrawal of king Lohrasb, King Goshtasb went on the throne instead of his father. At the time of Goshtasb reign, Zoroaster brought the religion of monotheism, and Goshtasb accepted his religion but Arjasb of Turan opposed him on this matter and they had many wars until finally Arjasb was killed by Esfandiyār son of Goshtasb.

Like father, Esfandiyār had the whim of throne, and as Goshtasb wouldn't be released of suffer of his 
requests, sent him to fight Rostam. The prince was killed by the hero of Sistan. Rostam, fostered Bahman to the request of his father Esfandiyār. After some time Rostam sent Bahman to his grandfather by his request. Goshtasb gave the kingdom to Bahman and passed away.

The background of Rostam and Esfandiyār story

In different parts of the Avesta and Pahlavi texts, Goshtasb is mentioned more than any other Kiyanid kings. Also, the information about Goshtasb kingdom in many Arabic and Persian sources matches what is mentioned in Shahnameh and stories of the rise of Zoroaster in his time and his reign during his father's life, battles with Arjasb of Turan and death of Esfandiyār by Rostam are mentioned.

About the death of Esfandiyār by Rostam and its reason Tabari writes that: Boshtasb that envied Esfandiyār, sent him to Sistan to fight with Rostam ... (Tabari, 1384: 480)

There are several words in Tarikh Alrosol Waalmolook (The History of Prophets and Kings) about repeated treacheries of Goshtasb in giving the throne to Esfandiyār, which eventually lead to the death of Esfandiyār: "I heard from Hisham ibn Muhammad Kelly that Goshtasb saved throne for his son Esfandiyār and sent him to fight the Turks from which he came back victorious. Then his father told him that 'Rostam have become well-off at the heart of our country and doesn't accept our reign. He says that king Kavoos gave the command of Sistan to him. Go and bring him to us.' Esfandiyāri went to fight Rostam and was killed" (Ibid: 8).

Gardezi History book mentions the rise of Zoroaster, imprisonment of Esfandiyāri by Goshtasb, Turanian Arjasb attack to Iran, capturing Esfandiyār's sisters (Homa and Afarid) and locking them in Roein castle (Ibid: 51).

\section{Form and meaning in the story of Battle of} Rostam and Esfandiyār

Dr. Taghi Poornamdarian says: "Two opposing forces are in conflict in human being: one is the soul or the rational self or heart that is the divine aspect of human, and the other is the animal soul, that is the essence of human nature and his animal aspect. The former is a symbol of light and the latter is a symbol of darkness. One takes human being towards the light, and the other towards darkness. Being an angel or a daemon depends on the success of one of the two. The battle of Rostam and Esfandiyār is the battle of these two forces. The Greater Jihad is the fight with the animal soul and inner enemy that is invulnerable like Esfandiyāri and no weapons works on him unless its only vulnerable organ, the eyes, that shoukd fail and be shut to worldly concerns. The soul can only defeat this enemy by the guidance of a Pir (master) or by joining the active intellect, the same as Rostam who overcomes Esfandiyār with the help of Zal and his guidance, who is in contact with Simorgh, and with the implementation of his divine essence and earning admissibility of Simorgh light" (Poornamdarian, 1367: 169-171).

About the battle of Rostam and Esfandiyār, Suhrawardi said "I told the Pir that 'I've heard that Simorgh fostered Zal, and Rostam overcame Esfandiyār with its help'. The Pir sad 'Yes that is true'. I said, 'how was it?' He said 'Rostam was so tired of fighting Esfandiyār and failed to overcome him so he went home. His father, Zal begged Simorgh. Simorgh has a property that if a mirror or something like that is put in front of Simorgh, any one that looks in the mirror and sees Simorgh will be dazzled.

Zal made an armor of iron that was all polished like a mirror and put it on Rostam. He himself put a polished [hood] on his head and hung several mirrors on his horse. Then he sent Rostam to the battle field facing Simorgh. Esfandiyāri had to come in front of Rostam. When he came near Rostam, Simorgh's beam reflected in the mirror armor and Esfandiyār saw Simorgh's picture. He was dazzled and had no vision, was hallucinated, and thought he was injured in both eyes because he had saw others, so he fell from horse and was killed by Rostam.'

As if those two pieces of tamarisk in the stories were from Simorgh's feather" (Poor Namdarian, 1388: 11-9).

Zal, Rostam and Esfandiyār story was quoted from the book "Red Intelect" because Suhrawardi has made additions and changes in the main story by his own interpretations. Now we read the explanations of the author of Mystery Stories In Persian Literature about the interpretations of Suhrawardi.

The two pieces of tamarisk narrated by Ferdowsi in Shahnameh as a two head arrow made of tamarisk 148 
wood that killed Esfandiyār are interpreted as Simorgh's feathers by Suhrawardi from the story of Angel. Also we can infer that the cause of Esfandiyār's death was the reflection of sunlight in his polished armor and mirrors that Rostam had on his horse. Therefore the two feathers of Simorgh are, actually, the codes for the angel of sun and the code for primary reason and general reason or any of the intellects.Each of the intellects are in fact The Necessary Being or Light of Lights.... Therefore Simorgh that is taken as the code for Sun Angel or the intellect of sun, can at the same time be both the code for the first intellect or the tenth intellect. (Poornamdarian, 1367: 171-169)

\section{Conclusions}

All the perceptions and beliefs of ancient religions can be clearly found in Shahnameh. These mythological ideas have found an epic form in Shahnameh, and then when they steppen in the coffee house paintings they found a visual form, so that these two forms of expression - literature and coffee house painting - are closely related, not only in terms of insight and the philosophy of creation, but also in terms of aestheticism and creating elements, too. So that the symbolism and imagery in both of them are the same and coincide in manycases. Master Mohammad Modabber, while loyal to the text, have pictured the struggle between good and evil and the triumph of good over evil in the coffee house painting of Battle of Rostam and Esfandiyār in the most eloquent form.

\section{References}

Ahmadi, Babak (2003). From visual signs to text, 3rd edition, Markaz publication, Tehran.

EslamiNodoushan, Mohammad Ali, (1376). The story of Rostam and Esfandiyār in Shahnameh, Sixth Edition, Asar Publication, Tehran.

FerdowsiAbolQasem (1996), Shahnameh corrected by Joolmool, translated by Dipache Jahangir Afkari, 2nd edition, ElmiFarhangi publication, Tehran.

MoeinMohamad, Persian dictionary, sixth vol, 8th press, Amir kabir publication

Poornamdarian, Taghi (1367). Secret and secret stories.2nd edition, ElmiFarhangi publication, Tehran.

Poornamdarian, Taghi (1367). The red intellect: A description and interpretation of stories by Suhrawardi. 1st edition, Sokhan, Tehran.

Tabari, Mohammad IbnJarir. (1384) The History of Prophets and Kings (chapter Iran, from the beginning to year 31 $\mathrm{AH})$, Translated by SadeqNeshat, Tehran, scientific and cultural publications.

Zamiran, Mohammad (1383). An introduction to artistic semiotics. 1st Press, Ghesseh publication, Tehran -32 . 